\title{
The Past, Present, and Future of Myocardial Revascularization
}

\author{
Budi Yuli Setianto \\ Department of Cardiology and Vascular Medicine \\ Faculty of Medicine Universitas Gadjah Mada - Dr. Sardjito Hospital Yogyakarta
}

\begin{abstract}
Corresponding author :
Budi Yuli Setianto, Prof, Dr, MD, - email: budyuls@ugm.ac.id

Department Cardiology and Vascular Medicine, Faculty of Medicine Universitas Gadjah Mada - Dr. Sardjito Hospital, Yogyakarta, Indonesia, Jalan Farmako Sekip Utara, Yogyakarta 55281
\end{abstract}

Manuscript submitted: October 2, 2017; Revised and accepted: January 24, 2018

\begin{abstract}
One of the important diagnostic modalities in cardiology is cardiac catheterization, which is one tool for myocardial revascularization. This examination is particularly useful in the aspect of cardiac hemodynamic evaluation, among other utilities. This review describes the advance of cardiac catheterization from the beginning of its discovery to future development.
\end{abstract}

Keyword: revascularization; cardiac catheterization

\section{INTISARI}

Salah satu modalitas diagnostik penting dalam kardiologi adalah kateterisasi jantung, yang merupakan salah satu cara revaskularisasi miokard. Pemeriksaan ini terutama berguna dalam aspek evaluasi hemodinamik jantung, diantara kegunaan yang lain. Tinjauan pustaka ini menerangkan perkembangan kateterisasi jantung dari awal mula penemuannya sampai perkembangan di masa depan.

\section{BACKGROUND}

One of the important diagnostic modalities in cardiology is cardiac catheterization. This examination is particularly useful in the aspect of hemodynamic evaluation that is to measure intra-cardiac pressure, blood saturation of the heart chambers, and cardiac output. Cardiac catheterization is one of the greatest discoveries in the field of cardiology in the $20^{\text {th }}$ century.

\section{DISCUSSION}

\section{History of Cardiac Catheterization}

The history of cardiac catheterization, angioplasty, and other catheter interventions is a remarkable journey and takes a long time. Around four hundred years has been passed to gradually change the method of cardiac catheterization until it finally becomes as advanced as it is today.
One major step that started this development was the discovery of a description of the human blood circulation by a British physician named William Harvey in 1628. Then, in 1706 Raymond de Vieussens, an anatomical professor from France for the first time described the structure of chambers and blood vessels of the heart. Furthermore, Stephen Hales, a British priest and scientist in 1711 performed a biventricular heart catheterization on a horse. More or less a century after Harvey's monumental discovery, Hales for the first time measured arterial blood pressure that became the next important milestone in the history of cardiac catheterization. Harvey and Hales became the main characters on two important moments that became milestones on the development of cardiac catheterization. Hales concrete steps followed other catheterization experimental procedures in the $19^{\text {th }}$ century. 
Claude Bernard in 1844 used a catheter to record intra-cardiac pressure in animals. $\mathrm{He}$ is a renowned physiologist from France who coined the term cardiac catheterization. Claude Bernard's scientific achievements with other scientists, such as Carl Ludwig and Etienne-Jules Marey, were the golden age of cardiovascular physiology at that time. ${ }^{1}$

The catheterization of the human heart grew in the twentieth century. A dramatic action by Werner Forssmann, a surgical resident in 1929 at Eberswald Germany, who performed right heart catheterization on himself. This action is the first recorded catheterization in humans, which is anesthetized his left elbow, inserting a catheter into the antecubital vein and positioning the catheter tip in the right atrium using an $\mathrm{x}$-ray. The original goal was to find an effective and safe pathway to include cardiac resuscitation drugs. Forssmann then developed his experiment toward intra-cardiac contrast media injection via a catheter placed in the right atrium. Such contributions, together with the development of nontoxic contrast media and radiological techniques, have paved the way for the development of coronary angiography. A decade after the phenomenal and therapeutic-oriented Forsmann catheterization, the first diagnostic cardiac catheterization by André Cournand and Dickinson Richards was introduced in 1941. They used cardiac catheters for diagnostic purposes to measure right heart and cardiac output. For their hard work, Forssmann, Cournand, and Richards were awarded the Nobel Prize in Medicine in 1956. In the 1950s, Zimmerman, Cope, Ross, and other scientists succeed to explore the left heart with a catheter. The first selective coronary arteriography in 1958 was introduced by Mason Sones. He performed this action on more than a thousand patients. A brief description of his technique was published in Modern Concepts of Cardiovascular Diseases in 1962. This development became the opening gate of a period of rapid advancement in aspects of coronary arteriography during the mid-1960s. ${ }^{2}$

The recanalization of peripheral arteries by catheters by accident by Charlod Theodore Dotter in 1963, further asserted the beginning of the intervening era. Dotter actually wanted to do an abdominal aortogram in a patient with renal artery stenosis by inserting a catheter percutaneously through a retrograde pathway. This catheter passes through the right iliac artery that is occluded, causing the artery to undergo a recanalization. Sones and Dotter's actions were followed by the percutaneous coronary femoral angiography method popularized by Melvin Judkins and Amplatz in 1967. Judkins was a radiologist who had studied coronary angiography with Sones. That year, Judkins created a coronary imaging system, introduced special catheters, and perfected the transfemoral approach. A more recent technique, angioplasty with balloons, was introduced by Andreas Gruentzig in the mid-1970s. Gruentzig also pioneered other catheter-based interventions during the decade. His pioneering has made significant progress in the improvement and development of catheterization techniques. ${ }^{3}$

At present, coronary angiography and percutaneous coronary intervention are performed primarily by the approach of radial arteries and femoral arteries. Sones technique is rarely used again. The discovery of Sones, Dotter, and Gruentzig above has led us to an era of well-equipped weapons of arterial revascularization equipment used for various clinical conditions. Beyond the domain of intervention, another historic momentum in cardiology was born in the early decades of the twentieth century, precisely in 1912, where cardiovascular disease caused by hardening of the arteries was first described by an American physician named James B. Herrick. Meanwhile, the discovery of $\mathrm{X}$-rays by Wilhelm Roentgen in 1895 enabled the study of cardiac anatomy to be 
carried out with this new approach. The discovery of X-rays was followed by the appearance of the first human radiographic coronary artery atlas in 1907. This atlas was created and published by two German doctors, Friedrich Jamin and Hermann Merkel. This development in the theoretical aspects of cardiology and radiology indirectly also influences developments in aspects of interventional cardiology. ${ }^{4}$

\section{Clinical Benefits}

The emergence of this great cardiologic discovery has helped solve cardiovascular problems. Cardiac catheterization can be applied to see the condition of coronary artery (coronary angiography) or right heart catheterization. Based on the executive summary of the guidelines for coronary angiography from the American College of Cardiology / American Heart Association (ACC ( AHA), this modality is used to:

1. Coronary artery disease that is known or newly suspected,

2. Valvular heart disease

3. Congenital heart disease

4. Congestive heart failure
5. Other conditions (i.e. diseases involving the aorta and hypertrophic cardiomyopathy).

Especially for coronary artery disease, coronary angiography is a standard criterion for diagnosis and is a primary method to help illustrate the anatomy of coronary arteries. Patients with known or suspected coronary artery disease may be stable angina, nonspecific chest pain, unstable angina, recurrent ischemia after revascularization, acute myocardial infarction, and in perioperative periods of non-cardiac surgery, usually recommended coronary angiography (i.e. with recommendation class I) if noninvasive examination results indicate a high risk, having a Canadian Cardiovascular Society III-IV class and undergoing medical therapy, suspected subsequent closure or subacute stromal thrombosis following percutaneous revascularization, or other important conditions. The use of right heart catheterization has several benefits:

1. To diagnose patients with congenital heart disease and obtain.

2. To monitor ICU patients with cardiovascular disease.

Table 1.Stenting unprotected left main coronary artery with drug eluting stents

\begin{tabular}{|c|c|c|c|c|c|c|}
\hline $\begin{array}{l}\text { Author } \\
\text { (Ref.No.) }\end{array}$ & $\begin{array}{c}\text { No. } \\
\text { of } \\
\text { patients }\end{array}$ & $\begin{array}{c}\text { Follow-up } \\
\text { (months) }\end{array}$ & $\begin{array}{c}\text { One-year } \\
\text { survival } \\
(\%)\end{array}$ & $\begin{array}{c}\text { MACE } \\
(\%)\end{array}$ & $\begin{array}{l}\text { Binary } \\
\text { restenosis } \\
(\%)\end{array}$ & Comments \\
\hline $\begin{array}{l}\text { Parketal. } \\
\text { (16) }\end{array}$ & 102 & 12 & 100 & 2 & 2 & $\begin{array}{l}\text { Both MACE events were reinterventions at the } \\
\text { lesion; the average MLD went from } 1.31 \text { to } \\
3.25 \mathrm{~mm} ; 84 \% \text { underwent follow- up angiogra- } \\
\text { phy demonstrating minimal late lumen loss }\end{array}$ \\
\hline $\begin{array}{l}\text { Chieffo et al. } \\
\text { (17) }\end{array}$ & 85 & 6 & 96.5 & 20 & 14 & $\begin{array}{l}\text { Patients tended to be a higher-risk cohort; the } \\
\text { MLD went from } 1.3 \text { to } 3.3 \mathrm{~mm} \text {; higher final } \\
\text { maximal pressures correlated inversely with } \\
\text { need for TLR }\end{array}$ \\
\hline $\begin{array}{l}\text { Suarez de } \\
\text { Lozo et al. } \\
\text { (18) }\end{array}$ & 52 & 12 & 100 & 4 & 2 & $\begin{array}{l}\text { There was an increase in MLD from } 1.1 \text { to } \\
3.2 \mathrm{~mm} \text {, with little late lumen loss; } 23 \text { of } \\
\text { patients underwent repeat angiogram to pro- } \\
\text { vide the } 2 \% \text { binary restenosis value }\end{array}$ \\
\hline $\begin{array}{l}\text { Valgimigli } \\
\text { et al. (19) }\end{array}$ & 80 & 16 & 86 & $\begin{array}{l}24 \text { (500 day } \\
\text { average } \\
\text { follow-up) }\end{array}$ & $3 \%$ & $\begin{array}{l}\text { Higher-risk patients with lower EF and higher } \\
\text { Parsonnet risk score; MLD went from } 1.1 \text { to } \\
3.25 \mathrm{~mm} \text {; MACE and survival include an addi- } \\
\text { tional } 15 \text { patients with protected left mains }\end{array}$ \\
\hline
\end{tabular}

Abbreviations: $\mathrm{MACE}=$ major adverse cardiac event, $\mathrm{MLD}=$ minimum luminal diameter, $\mathrm{TLR}=$ target lesion revascularization, $\mathrm{EF}=$ ejection fraction. (Table source: Park et al., 2005) ${ }^{6}$ 
3. When placed in the right auricular proximal, the catheter can be an important and safe route for administration of fluids, medications, and parenteral nutrition.

4. For physiological studies of cardiovascular dynamics in both normal individuals and patients with heart disease.

\section{Current Developments}

More than 70 years since Forsmann's phenomenal action, percutaneous coronary intervention has shifted the position of coronary artery bypass surgery to become a more common procedure in many countries. Includes stent implantation on unprotected left main disease, which was always indicated bypass operation. (Table 1. $)^{6}$

The frequency of its implementation continues to grow. The success rate is over $95 \%$ with the risk of serious complications declining. Patients can be mobilized immediately and discharged on the same day or the next day. The recurrent stenosis that becomes a scourge now slowly begins to diminish. The success of percutaneous intervention is closely related to the developments, such as:

1. Improved quality of intra-coronary and balloon guide wire thus enhancing the level of safety and effectiveness.

2. Increased diversity of balloons, stents, and other devices mounted with the help of a catheter.

3. Replace the contrast media used.

Progress is the fastest in terms of stent development. These stents are made of stainless steel tubes and have different strength and flexibility. After being cut using laser light, the tubes are shaped into a variety of stent designs. They are chemically scratched, electroplated into fine final results, and sometimes coated. We have available various types of stent. There are regular stents that do not contain drugs called bare-metal stents (BMS). This BMS discovery was the second revolution in the world of interventional cardiology after the first revolution by Gruentzig. The risk of restenosis (occurrence that occurs after stent implantation) due to tissue growth has led to the emergence of another stent variance drug-eluting stent (DES). This stent contains drugs to prevent or delay tissue proliferation. Its use has reduced the incidence of stenosis again compared to the use of BMS. This was first observed in the RAVEL study, a randomized study comparing stent containing sirolimus with standard stent. Stent, in particular DES, reduces the risk of restenosis but is also associated with other risks of stent thrombosis. Therefore, dual anti-platelet therapy (DAPT) is necessary for patients who use it.

The development of the next stent considered the fourth revolution is the invention of bioresorbable vascular scaffold (BVS). This technology allows temporary scaffolding of the blood vessels to prevent acute closure. Antiproliferation drugs are temporarily elaborated to overcome the constrictive remodeling and hyperplasia of excessive intima layers. One of the advantages of this invention is the reduction in the side effects of stent thrombosis. In addition, scaffolding is only temporary until the blood vessels heal. No foreign matter is a potential trigger for stent thrombosis (such as nonendothelial strut and drug polymer) that persists for a long time.

Other advances achieved are in terms of contrast media and the application of digital technology to angiography. Early in its appearance, the angioplasty procedure used a toxic contrast medium. Relatively safe contrast media has now replaced it. The digital angiography system is a major advance that goes beyond the old cine-based systems.In addition to aspects of coronary intervention, the development of cardiac catheterization also penetrated aspects of cardiovascular critical care. 
Right heart catheterization has developed into pulmonary artery catheterization. This examination was first introduced to the intensive care unit about 40 years ago. Despite the lack of evidence demonstrated by controlled randomized studies of its clinical utility, pulmonary artery catheterization has become the standard of care for patients with critical illness. ${ }^{5}$

\section{CONCLUSION}

Coronary revascularization begins with the description of the human blood circulation, then followed by a picture of the structure of the chamber and blood vessels of the heart. Furthermore, coronary angiography in animal models, initiates angiography procedures in humans. Percutaneous coronary intervention $(\mathrm{PCl})$ is currently highly advanced from angioplasty to stent implantation, from BMS to BVS. Along with the development of non-toxic contrast media security and various devices for implantation of stent, shifting the bypass of coronary arteries by $\mathrm{PCl}$ and its use is more prominent in many countries. The advancement of today's digital angiography system extends beyond the old cine-based systems. In addition, cardiac catheterization is often used in critical cardiovascular care.

\section{REFERENCES}

1. History of the heart [Internet]. 2013 [cited 2013 Nov 18]. Available from: http://www. fi.edu/learn/heart/history/firsts.html.

2. Braunwald E., Gorlin R., Mclntosh H.D., Ross R.S., Rudolph A.M., Swan H.J. 1968. Cooperative study on cardiac catheterization. Summary. Circulation, 37(5 Suppl): III93-101.

3. Mehta N.J., Khan I.A. 2002. Cardiology's 10 greatest discoveries of the 20th century. Tex Heart Inst J, 29:164-171.

4. Mueller R.L., Sanborn T.A. 1995. The history of interventional cardiology: cardiac catheterization, angioplasty, and related interventions. Am Heart J, 129:146-172.

5. Bourassa M.G. 2005. The history of cardiac catheterization. Can J Cardiol, 21: 10111014.

6. Park S.J., Kim Y.H., Lee B.K., Lee S.W., Lee C.W., Hong M.K., et al. 2005. Sirolimuseluting stent implantation for unprotected left main coronary artery stenosis. J Am Coll Cardiol, 45:351-356. 